\title{
ANALISIS PENDIDIKAN KARAKTER BERBASIS KELUARGA KARYA Dr. H. AMIRULLAH SYARBINI, M. Ag.
}

\author{
Muhammad Abdul Halim Sidiq
}

Email : dulhalim2528@gmail.com

Institut Agama Islam Syarifuddin Lumajang, Indonesia

\author{
Rika Fausiyah \\ Email : rikafausiyah@gmail.com \\ Institut Agama Islam Syarifuddin Lumajang, Indonesia
}

\begin{abstract}
Abstrak
Karakter dimaknai dengan nilai-nilai yang baik (tahu nilai kebaikan, mau berbuat baik, dan nyata berkehidupan baik) yang terpatri dalam diri dan perilaku. Karakter merupakan ciri khas seseorang atau sekelompok orang yang mengandung nilai, kemampuan, dan ketegaran dalam menghadapi kesulitan dan tantangan.

Fenomena kerusakan moral/akhlak yang menimpa masyarakat tersebut telah mendorong pemerintah Indonesia untuk menerapkan Kebijakan Nasional Pembangunan Karakter Bangsa (KN-PKB). Salah satu mewujudkan kebijakan tersebut adalah dengan menekankan pentingnya pendidikan karakter untuk diimplementasikan dalam setiap institusi pendidikan, baik formal (sekolah), informal (keluarga), maupun non formal (masyarakat).

Pendidikan karakter akan berjalan efektif dan utuh jika melibatkan tiga institusi, yaitu keluarga, sekolah, dan masyarakat. Pendidikan keluarga berperan penting karena keluargalah yang membentuk karakter seorang anak. Untuk merumuskan kerangka model pendidikan karakter dalam keluarga dapat dikonseptualisasi melalui pendekatan system pendidikan. Jika istilah system dikaitkan dengan pendidikan (sistem pendidikan), maka dapat mengandung makna "suatu kesatuan komponen yang terdiri dari unsur-unsur pendidikan yang bekerjasama dan berhubungan antara satu dengan yang lainnya untuk mencapai tujuan pendidikan." Dalam suatu sistem terdapat unsure-unsur, bagian-bagian, atau komponen-komponen yang saling berkaitan dan teratur, serta mekanismenya saling berhubungan dalam satu kesatuan yang semuanya di tujukan untuk mencapai satu tujuan. Isi kerangka model pendidikan karakter meliputi komponen: tujuan, pendidik, peserta didik, materi, metode, alat, program, dan evaluasi.
\end{abstract}

Kata kunci : Pendidikan Karakter, Berbasis Keluarga 


\section{Pendahuluan}

Di era globalisasi ini rusaknya karakter dapat muncul dari bergai aspek yakni diantaranya dari dalam keluarga, pergaulan dan masyarakat sekitar, semuanya dapat dicegah dengan pondasi utama yaitu keluarga. Keluarga memiliki peran yang sangat penting dalam ikhtiar orang tua dan perawatan orang tua yang penuh kasih dan pendidikan tentang nilai-nilai kehidupan, baik agama maupun sosial budaya, merupakan faktor yang sangat kondusif untuk mempersiapkan anak menjadi pribadi yang unggul kelak.

Keluarga merupakan unit atau institusi sosial terkecil yang dapat memenuhi kebutuhan insani dalam mengembangkan kepribadian anak, baik kebutuhan fisik-biologis maupun sosio-psikologisnya. Namun, sebagai pendidik pertama dan utama, orang tua tidak hanya dituntut untuk mengajarkan nilai-nilai kehidupan positif tersebut, tetapi juga harus meneladankannya dalam kehidupan sehari-hari.

Bangsa Indonesia saat ini sedang mengalami kerusakan moral akhlak hampir pada semua segmen kehidupan dan seluruh lapisan masyarakat. Berbagai kerusakan moral di atas mengindikasikan telah terjadinya pergeseran nilai etika dalam kehidupan berbangsa dan bernegara serta memudarnya kesadaran masyarakat terhadap nilai-nilai agama, budaya, dan falsafah bangsa. Dampaknya, hilanglah nilai-nilai karakter yang melekat pada bangsa kita sebelumnya, seperti rasa malu, kejujuran, kesantunan, kebersamaan, tanggung jawab, patriotik, kepedulian sosial, dan sebagainya.

Secara makro, pengembangan pendidikan karakter dapat dibagi dalam tiga tahap, yakni perencanaan, pelaksanaan/implementasi, dan evaluasi hasil. Pada tahap perencanaan dikembangkan perangkat/nilai- 
nilai karakter yang digali dan dikristalisasikan. ${ }^{1}$ Pada tahap implementasi dikembangkan pengalaman belajar (learning experiences) dan proses pembelajaran yang bermuara pada pembentukan karakter dan dalam diri individu peserta didik. Proses ini dilaksanakan melalui proses pembudayaan dan pemberdayaan sebagaimana digariskan sabagai salah satu prinsip peanyelenggaraan pendidikan nasional. Proses ini berlangsung dalam tiga pilar pendidikan, yakni dalam satuan pendidikan, keluarga, masyarakat. Pada tahap evaluasi hasil, dilakukan asesmen program untuk perbaikan berkelanjutan yang sengaja dirancang dan dilaksanakan untuk mendeteksi aktualisasi karakter dalam diri peserta didik sebagai indikator bahwa proses pembudayaan dan pemberdayaan karakter itu berhasil dengan baik.

Sementara itu, pada tataran mikro, pengembangan pendidikan karakter dibagi dalam empat pilar, yakni kegiatan belajar mengajar di kelas, kegiatan keseharian dalan bentuk budaya satuan pendidikan ( school culture), kegiatan kurikuler dan/atau ekstrakurikuler, serta kegiatan keseharian dirumah dan dalam masyarakat. Dalam kegiatan pembelajaran dikelas, pengembangan nilai/karakter dilaksanakan dengan menggunakan pendekatan terintegrasi dalam semua mata pelajaran (embeded approach). Khusus untuk mata pelajaran pendidikan agama dan pendidikan kewarganegaraan. Karena misinya adalah mengembangkan nilai dan sikap, maka penegmbangan nilai/karakter harus menjadi fokus utama yang dapat menggunakan berbagai strategi/metode pendidikan nilai.

Dalam kegiatan kurikuler, yakni kegiatan belajar di luar kelas yang terkait langsung dengan suatu materi dari suatu mata pelajaran, atau kegiatan dan tidak terkait langsung dengan suatu mata pelajaran, perlu

\footnotetext{
${ }^{1}$ Kementrian Pendidikan Nasional, “Desain Induk Pendidikan Karakter.” Dalam Pendidikan KarakterBerbasis Keluarga. Amirullah Syarbini (Jogyakarta: Ar-Ruzz Media, 2016), 15-18.
} 
dikembangankan proses pembiasaan dan penguatan dalam rangka pengembngn nilai/karakter. Selanjutnya, di lingkungan keluarga dan masyarakat diupayakan agar terjadi proses penguatan dari orangtua/wali serta tokoh-tokoh masyarakat terhadap perilaku berkarakter mulia yang dikembangkan seatu pendidikan menjadi kegiatan keseharian dirumah dan lingkungan masyarakat masing-masing. ${ }^{2}$

Berdasarkan grand design pengembangan pendidikan karakter secara makro dan mikro diatas, dapat dikatakan bahwa pendidikan karakter akan berjalan efektif dan utuh jika melibatkan institusi, yaitu keluarga, sekolah, dan masyarakat. Pendidikan karakter tidak akan berjalan dengan baik jika mengabaikan salah satu institusi, terutama keluarga. Pendidikan informal dalam keluarga memiliki peran penting dalam proses pembentukan karakter seseorang. Oleh karena itu, keluarga sebagai lingkungan pembentukan karakter pertama dan utama mestilah diperdayakan kembali. Penanam karakter terpuji, seperti jujur, berani, disiplin, kerja sama, tegas, ramah, sabar, mandiri, tanggung jawab, kasih sayang, dan peduli akan terwujud dalam keluarga sakinah. Hal itu disebabkan orangtua dalam keluarga sakinah diasumsikan dapat melaksanakan pendidikan karakter terhadap anak secara baik sejak dini. Penanaman karakter mulai tidak bisa dilakukan secara singkat, akan tetapi melalui proses yang terusmenerus sejak dini hingga mencapai taraf kedewaaan atau kematangan.

Berbagai paparan di atas mengisaratkan adanya keterkaitan yang signifikan antara penanaman nilai-nilai karakter yang dilakukan orangtua terhadap anak dengan karakter anak sesungguhnya dimasa depan. Artinya, bagaimana model penanaman nilai yang dilakukan terhadap orangtua terhadap anak akan memengaruhi bagaiman karakter individu

\footnotetext{
2 Amirullah Syarbini, Pendidikan KarakterBerbasis Keluarga, ( Jogyakarta: Ar-Ruzz Media, 2016), 11.
} 
yang bersangkutan, dan pada akhirnya hal tersebut akan menjadi identitas yang bersangkutan pada masa yang akan datang. ${ }^{3}$

\section{Pendidikan Karakter}

Secara sederhana, karakter diartikan sebagai sifat- sifat kejiwaan, akhlak atau budi pekerti yang membedakan seseorang dengan yang lainnya, tabi'at dan watak (KBBI, 1990). Karakter juga menyangkut bagian dari ciri kepribadian seseorang. Menurut Morison, kepribadian adalah apa yang dicapai seseorang individu dengan menampilkan hasil- hasil kultural dan evolusi sosial. Sementara C. H. Judd menyatakan, bahwa kepribadian adalah hasil lengkap, serta merupakan hasil keseluruhan dari peoses perkembangan yang telah dilalui individu.4

Dalam kajian psikologi kepribadian diungkapkan, bahwa ada dua aspek utama, yang membentuk kepribadian, yakni :1) temperamen; dan 2) watak (karakter). Temperamen menyangkut aspek biologis yang disandarkan pada konstitusi tubuh. Berdasarkan pendekatan ini muncul sejumlah pendapat mengenai tipe kepribadian manusia. Hypocrates dan Galenus menyatakan bahwa tipe kepribadian dipengaruhi oleh jenis cairan yang dominan dalam tubuh Lalu Kretchmer membagi tipe kepribadian atas dasar bentuk tubuh. Sedangkan Sheldon menyusun pembagian tipe kepribadian ini berdasarkan dominasi lapisan dalam tubuh tampaknya para pakar ini melihat hubungan antara komposisi unsur kimiawi tubuh, bentuk tubuh dan tipe kepribadian seseorang. Unsurunsur kimiawi tubuh yang berpengaruh dalam pembentukan aspek dari kepribadian yang disebut temperamen. Sebaliknya aspek watak atau karakter terbentuk oleh intervensi dari luar, khususnya melalui

\footnotetext{
3 Jalaluddin, Metode Penelitian Komunikasi, (Bandung: Rosdakarya 2012) 41

${ }^{4}$ Jalaluddin, Metode Penelitian Komunikasi, 202
} 
pendidikan. Pembentukan karakter pada dasarnya adalah wujud dari upaya sadar yang dilakukan untuk mengubah sikap dan perilaku.

Sebagai sikap batin, karakter atau watak termasuk unsur kepribadian yang dapat diubah. Menurut Prof. Mar'at, sikap dipandang sebagai seperangkat reaksi- reaksi afektif terhadap objek tertentu berdasarkan hasil penalaran, pemahaman, dan penghayatan individu. ${ }^{5}$ Sikap merupakan predisposisi untuk bertindak senang atau tidak senang terhadap objek tertentu yang mencakup komponen kognisi, afeksi dan konasi. Dengan demikian sikap merupakan interkasi dari komponenkomponen tersebut secara kompleks. Dengan demikian sikap terbentuk dari hasil belajar dan pengalaman seseorang. Jadi bukan faktor bawaan.

Dorothy Law Notle menghubungkan pembentukan sikap melalui proses belajar. Dorothy Law Notle mencoba melukiskan proses dimaksud dalam sebuah puisi berjudul "Children Learn What They Live" Anakanak belajar dari kehidupan mereka.

Jika anak dibesarkan dengan celaan, ia belajar memaki, Jika anak dibesarkan dengan permusuhan, ia belajar berkelahi, Jika anak dibesarkan dengan cemoohan, ia belajar rendah diri, Jika anak dibesarkan dengan hinaan, ia belajar menyesali diri, Jika anak dibesarkan dengan toleransi, ia belajar menahan diri, Jika anak dibesarkan dengan dorongan, ia belajar percaya diri, Jika anak dibesarkan dengan pujian, ia belajar menghargai, Jika anak dibesarkan dengan sebaik-baik perlakuan, ia belajar keadilan, Jika anak dibesarkan dengan rasa aman, ia belajar menaruh kepercayaan, Jika anak dibesarkan dengan dukungan, ia belajar menyenangi diri, Jika anak dibesarkan dengan kasih sayang dan persahabatan, Ia belajar menemukan cinta dalam kehidupan. ${ }^{6}$

Puisi gubahan Dorothy Law Notle ini menyibak sejumlah rahasia tentang pendidikan anak. Pertama, anak akan belajar dari pengalaman

${ }^{5}$ Mar'at, Sikap Manusia Perubahan Serta Pengukurannya, (Jakarta : Ghalia Indonesia 1982), 19

${ }^{6}$ Jalaluddin, Metode Penelitian Komunikasi, 187

Bidayatuna | p-ISSN: 2621-2153, e-ISSN: 0000-0000 | 84 
yang ia peroleh dari lingkungan dan perlakuan yang diterimanya. Dari ramuan pengalaman dan perlakuan ini pula sikap dan perilaku anak- anak terbentuk. Kedua, pendidikan merupakan proses yang panjang dan berkesinambungan. Untuk membentuk anak menjadi sosok pribadi tertentu, para pendidik mesti merancang bentuk maupun strategi bimbingan yang diinginkan. Ketiga, pendidikan adalah juga merupakan proses pembiasaan.

\section{Mulai Dari Keluarga}

Setiap orangtua pasti menginginkan putra- putri mereka menjadi manusia yang pandai, cerdas, dan berakhlak. Namun sayangnya keinginan tersebut tidak disertai oleh upaya-upaya yang positif dan kondusif. Terkadang malah menyimpang dari apa yang mereka rencanakan. Kehidupan keluarga yang kurang harmonis umumnya menjurus kepada pertengkaran terbuka antara bapak dan ibu. Kasus ini bisa menimbulkan sikap memihak, ragu terhadap diri dan kegoncangan batin pada anak. ${ }^{7}$

Demikian pula bila perlakuan orangtua terhadap anak terlalu keras (otoriter), akan kehilangan harga diri. Mayasari Oei mengemukakan sebuah kasus mengenai penyimpangan ini. Dalam tulisannya berjudul “Kekuatan Mendidik Tanpa Kekerasan" mengungkapkan kasus "kekerasan" dalam sebuah keluarga "F", laki- laki etnis Cina, kini berusia 33 tahun, berhasil meraih gelar strata dua, tetapi tidak pernah berhasil diterima di perusahaan manapun ia melamar. Sudah ratusan lamaran F kirim, tapi tak ada satupun perusahaan yang memanggil $\mathrm{F}$ untuk bekerja. F sebenarnya pintar, itu terbukti dari kemampuannya menyelesaikan studi S2, namun belum mampu menyelesaikan konflik masa kecilnya ketika F pernah disakiti secara verbal dan fisik oleh sang ibu.

\footnotetext{
${ }^{7}$ Gunarsa D Singgih, Psikologi Remaja, (Jakarta : BPK Gunung Agung 1981) 34
} 
Ketika berusia 8 tahun, F pernah melakukan kesalahan, yaitu lupa mematikan keran air sampai air pun luber, akhirnya ibu F mengetahui hal itu dan marah besar. Kondisi ekonomi saat itu sedang sulit- sulitnya, setetes air begitu berharga, ibu F marah besar dan menghukum F. F ditelanjangi di depan pagar rumahnya dan dihukum berdiri selama beberapa jam. Ketika F berdiri, orang- orang bisa melihatnya berdiri tanpa busana. Kenangan memalukan itu terus tersimpan dalam memori dan alam bawah sadar F. Beranjak dewasa, F tumbuh menjadi seorang remaja yang malu, sensitif, penakut, dan menjadi korban bullying teman-teman sebayanya.

Perlakuan keluarga terhadap anak ternyata memiliki dampak yang besar bagi pembentukan kepribadian anak. Keluarga merupakan lembaga pertama dalam kehidupan anak, tempat pertama bagi anak untuk belajar dan berkembang sebagai manusia yang utuh dan makhluk sosial. Orangtua adalah pihak yang seringkali bersinggungan dengan seorang anak dalam kehidupan sehari-hari. Dengan demikian keluarga menyediakan hubungan sosial dan lingkungan yang penting demi kebutuhan permelajaran pertama anak mengenai manusia, situasi, dan keterampilan yang kelak akan digunakan sepanjang hayatnya. ${ }^{8}$

Bila ditelusuri secara cermat, sejatinya muatan yang teramu dalam gubahan Dorothy Law Notle dimaksud, sudah harus diawali sejak usia dini. Tepatnya sejak masa bayi. Penerapannya mulai dari aktivitas keseharian di lingkungan keluarga. Proses pembentukan yang dilakukan melalui pembiasaan. Sebab pendidikan sendiri hakikatnya adalah pembiasaan. Melatih pada kebiasaan yang baik. Pembentukan kebiasaan akan lebih efektif bila didukung oleh sosok teladan yang dapat dijadikan

\footnotetext{
8 Wuri Prasetyawati, Hubungan persepsi terhadap pola Asuh orangtua dengan penyesuaian diri pada mahasiswa Universitas Indonesia. Skripsi strata satu Fakultas Psikologi Universitas Indonesia.
} 
panutan. Kedua faktor ini memang tersedia dalam kehidupan keluarga, yakni kedua orangtua.

Bayi yang baru lahir merupakan makhluk yang tidak berdaya. Namun ia dibekali berbagai kemampuan yang bersifat bawaan, atau faktor bawaan. Bayi memerlukan pengawasan, serta pemeliharaan yang terus menerus sebagai latihan dasar dalam pembentukan kebiasaan dan sikapsikap tertentu, agar ia memiliki kemungkinan untuk berkembang secara wajar dalam kehidupan di masa dating. Di sini terlihat kalau dalam pertumbuhan (fisik) dan perkembangan (mental spiritual) bayi memerlukan intervensi dari lingkungan yang kondusif.

Dalam pandangan Islam, faktor bawaan dimaksud adalah fitrah. Potensi fitrah, yakni "fitrah Allah yang menciptakan manusia atas fitrah itu “( Q. 30: 30 ). Menurut Murthada Muthahhari fitrah berkaitan dengan keadaan manusia dan hubungan keadaan tersebut dengan agama9 ${ }^{9}$ Senada dengan itu, Menurutnya, fitrah adalah sesuatu yang melekat pada diri manusia sejak kelahirannya. Hal ini berarti manusia tidak dapat melepaskan diri dari agama. ${ }^{10}$ Fitrah sebagai potensi tauhid, yakni berupa kecenderungan untuk tunduk kepada Sang Maha Pencipta.

Sebagai sebuah potensi, maka fitrah masih perlu dikembangkan melalui bimbingan dan arahan. Tugas utama untuk melakukan hal ini dibebankan kepada kedua orangtua. “ Setiap bayi dilahirkan dalam keadaan fitrah. Maka kedua orangtuanyalah yang akan menjadikan ia seorang, Nasrani, Yahudi atau Majusi," jelas Rasul Allah Saw. Di sini terlihat bahwa muatan fitrah mengacu kepada nilai- nilai aqidah, hingga tugas kedua orangtua dalam "memelihara' dan " mengembangkannya" dikaitkan dengan nilai- nilai ajaran agama.

\footnotetext{
${ }^{9}$ Murtadha Muthahhari, Perspektif Al-Qur'an Tentang Manusia Dan Agama, terj. Haidar Baqir (Bandung: Mizan, 1994) 8.

${ }^{10}$ Quraish Shihab, Wawasan Alqur'an, (Jakarta : Mizan 1996) 376
} 
Mengapa demikian? Pertama, lingkungan yang paling awal dikenal manusia adalah keluarga. Kedua, bayi mula- mula mengenal sosok ayah dan ibu sebagai manusia yang paling dekat dengannya. Ketiga, sebagai pendidik kodrati kedua orangtua sudah dibekali oleh Sang Maha Pencipta, naluri kebapakan dan keibuan. Dengan demikian keduanya dibekali kemampuan alami untuk mengayomi, membimbing, maupun mengasih- sayangi putra putri mereka.

Dengan kelengkapan yang dimiliki, maka cukup pantas bila Islam meletakkan tanggungjawab pendidikan sebagai bagian dari kewajiban agama.

Dalam kajiannya Murdock (1949) dan Haviland mengungkapkan bahwa keluarga memiliki dua fungsi. Pertama, menyangkut masalah seksual. Fungsi kedua adalah pemeliharaan anak. Dalam fungsi ini, selain menyangkut pemeliharaan fisik juga termasuk pembentukan karakter dan perilaku anak untuk bisa hidup di kalangan yang lebih luas, yaitu masyarakat. Pepatah " buah jatuh tak jauh dari pohonnya", menunjukkan bahwa bagaimana anak dibentuk melalui hubungannya dengan kedua orangtua. Kewajiban kedua orangtua dalam mendidik anak meliputi penataan suatu lingkungan dalam suasana yang kondusif dalam kehidupan keluarga. ${ }^{11}$

Dalam pandangan Erich Fromm lingkungan kondusif bagi pendidikan mencakup lingkungan bendawi dan manusiawi. Kedua lingkungan ini merupakan faktor yang punya dampak dominan bagi pembentukan sikap dan perilaku seseorang. Lingkungan bendawi adalah penataan benda- benda yang bernilai pendidikan di sekitar lingkungan anak, utamanya dalam keluarga. Sedangkan yang dimaksud dengan lingkungan manusiawi adalah sosok keteladan yang diperlihatkan orang-

11 Eko Meinarno, Manusia Dalam Kebudayaan Masyarakat, (Jakarta : Salemba Humanika 2010) 7 
orang yang berada di lingkungan anak, khususnya keluarga. Kedua faktor ini ikut memberi pengaruh positif dan menentukan bagi terwujudnya pembentukan sikap dan perilaku yang dikehendaki.

Demikian besar dan dominannya pengaruh lingkungan dimaksud, sampai- sampai Gilbert Highest menyatakan, bahwa kebiasaan yang dimiliki anak- anak sebagian besar terbentuk oleh pendidikan keluarga. Sejak dari bangun tidur, hingga ke saat akan tidur kembali, anak- anak menerima pengaruh dan pendidikan dari lingkungan keluarga. Ungkapan Gilbert Highest ini setidaknya mengisyaratkan penting dan stategisnya fungsi dan peran keluarga, khususnya kedua orangtua, dalam membentuk karakter. Pembentukan melalui proses pembiasaan dalam kehidupan sehari-hari dalam keluarga. Dimulai dari hal- hal yang paling mendasar, yakni asupan makanan dan minuman, serta pola asuh.

\section{Analisis Pendidikan Karakter Berbasis Keluarga}

Pemikiran Dr. H. Amirullah Syarbini, M. Ag terhadap model-model pendidikan karakter dalam keluarga dalam buku pendidikan karakter berbasis keluarga. Ada beberapa pemikiran diantaranya :

1. Model adalah kerangka konseptual atau prosedur yang sistematis mengenai suatu hal yang berfungsi sebagai pedoman atau contoh bagi pihak yang lain yang ingin mengikutinya. Adapun model yang akan disusun dalam jurnal ini termasuk model normtaif, yaitu model yang menyediakan jawaban terbaik terhadap satu persoalan. Model ini meberi rekomendasi dalam keluarga, baik terhadap Tuhan Yang Maha Esa, diri-sendiri, sesam manusia, maupun tindakan-tindkan yang perlu diambil, khususnya dalam proses pendidikan karakter dikeluarga. Istilah "model" tersebut jika disandingkan dengan "pendidikan karakter dalam keluarga" dapat diartikan sebgai kerangka konseptual 
dan prosedur yang sistematis berkenaan dengan upaya penanaman nilai-nilai karakter kepada anak yang dilakukan oleh orangtua linhkungan sekitar. Kerangka konseptual itu kemudian dapat dijadikan rujukan oleh orang lain yang ingin mengemplementasikan pendidika karkater dalam keluarga. ${ }^{12}$

Model merupakan kerangka konseptual yang dipergunakan sebagai pedoman atau acuan dalam melakukan suatu kegiatan. Model juga merupakan seperangkat prosedur yang sistematis untuk mewujudkan suatu proses kegiatan. ${ }^{13}$ Model merupakan gambaran yang telah terkonsep secara terstruktur di jadikan pedoman sebagai upaya penanaman nilai karakter terhadap anak.

2. Tujuan pendidikan karakter dalam keluarga secara khusus adalah membina dan mengrahkan anak-anak agar memiliki karakter yang baik atau akhlak yang terpuji, sedangkan secara umum bertujuan untuk menyiapkan anak agar dapat hidup optimal dan bermanfaat, baik bagi dirinya, keluarganya, masyarkat, maupun agam dan bangsanya. ${ }^{14}$

Tujuan pendidikan karakter adalah membangun kepribadian dan budi pekerti yang luhur sebagai modal dasar dalam berkehidupan ditengah-tengah masyarakat, baik sebagai umat beragam maupun dalam kehidupan berbangsa dan bernegara. Jika kita melihat tujuan pendidikan karakter yang demikian, pada dasarnya pendidikan karakter itu adalah pendidikan akhlak terpuji, yaitu pendidikan yang mengajarkan, membina, membimbing dan melatih peserta didik agar memiliki karakter, sikap mental positif, dan ahklak yang

\footnotetext{
${ }^{12}$ Amirullah Syarbini, Pendidikan, 105-106.

${ }^{13}$ Muhaimin et. al., Paradigma Pendidikan Islam ,(Bandung: Remaja Rosdakarya, 2008), 221.

${ }^{14}$ Amirullah Syarbini, Pendidikan, 112.
} 
terpuji. ${ }^{15}$ Pendidikan karakter merupakan usaha terencana untuk meningkatkan kepribadian seseorang baik itu sifat atau tingkah lakunya ke tahap yang lebih baik.

3. Pengajaran atau pembelajaran itu mengandung beberapa implikasi. Pertama, pengajaran tidak sekedar melinatkan pendidikan, tetapi juga peserta didik. Dalam pengajran terjadi interaksi timbal balik anatar pendidikan dan peserta didik. Keduan, pengajarn tidak sebatas memberikan pengetahuan kepada peserta didik, tetapi juga menghasilak perubahan perilaku peserta didik kearah yang lebih baik sesuai dengan tujuan yang dirumuskan. Ketiga, pengajaran pada dasarnya adalah upaya membuat peserta didik dapat belajar, butuh belajar, mau belajar, terdorong belajar, dan tertarik terus-menerus untuk belajar. ${ }^{16}$

Dalam konteks pendidikan karakter di keluarga, pengajarn dapat diartikan sebagi suatu upaya yang dilakukan oleh orangtua untuk memberikan pengetahuan kepada anak tentang nilai-nilai karakter tertentu, dan membimbing serta mendorongnya untuk mengaplikasikan nilai-nilai tersebut dalam kehidupan sehari-hari. ${ }^{17}$

Kegiatan pengajaran dapat terjadi dengan direncanakan dan dapat pula terjadi tanpa direncanakan. Pengajaran karakter yang direncanakan adalah aktifitas pengajaranyang secara sadar dirancang untuk membantu peserta didik dalam mengembangkan pengetahuan tentang nilai-nilai karakter yang berikutnya diwujudkan dalam sikap dan prilaku keseharian. Sementara pengajaran yang tidak direncanakan adalah fenomena yang berupa peristiwa kehidupan

\footnotetext{
${ }^{15}$ Mohammad Haitami Salaim, Pendidikan Agaman Dalam Keluarga ,(Yogyakarta: Ar-Ruzz Media, 2013), 34.

16 Amirullah Syarbini, Pendidikan, 114-115.

17Ibid., 115.
} 
tanpa disengaja atau direncanakan, namun dampaknya dapat mempengaruhi, mengubah, dan mengembangakan karakter serta kepribadian anak. Dalam konteks kehidupan rumah tangga, aktifitas pengajaran tampaknya lebih banyak tanpa direncanakan yaitu melalui berbagai peristiwa yang terjadi dalam rumah yang dapat mempengaruhi karakter anak. ${ }^{18}$

Pengajaran adalah aktivitas membimbing kegiatan belajar anak. ${ }^{19}$ Pengajaran adalah suatu cara bagaimana mendidik karakter anak. Dengan kata lain pengajaran adalah suatu proses yang dilakukan oleh para guru atau orang tua dalam membimbing, membantu, dan mengarahkan anak atau peserta didik untuk agar memiliki karakter yang lebih baik.

4. Pemotivasian adalah proses mendorong dan menggerakkan seseorang agar mau melakukan perbuatan-perbuatan tertentu sesuai dengan tujuan yang diharapkan. Dalam konteks pendidikan karakter dikeluarga, pemotivasian dapat dimaknai sebagi upaya-upaya menggerakkan atau mendorong anak untuk mengaplikasikan nilainilai karakter. Berkaitan dengan itu, orang tua dituntut untuk mampu menjadi motivator bagi anak-anaknya. Selanjutnya, agar anak-anak tergerak untuk melakukan nilai-nilai karakter, orang tua harus mampu menjadi teladan terbaik dalam keluarga, disinilah, keteladanan orangtua merupakan cara paling jitu untuk menenamkan karakter pada diri anak. ${ }^{20}$

Motivasi didefinisikan oleh Maslow sebagai proses psikologika seseorang yang menyebabkan terjadinyan perbuatan-perbuatan secara

\footnotetext{
${ }^{18}$ Amirullah Syarbini, Pendidikan, 115-116.

${ }^{19}$ Oemar Hamalik, psikologi Belajar dan Mengajar (Bandung: Sinar Baru Algensido, 2009), 58.

20 Amirullah Syarbini, Pendidikan, 119.
} 
sukarela yang diarahkan untuk mencapai tujuan tertentu. ${ }^{21}$ Pemotivasian adalah upaya sadar agar dapat menggerakkan dan menyemangati seorang anak agar bertidak/berprilaku baik, sehingga tanpa di sadari karakter baik tersebut dapat tertanam dalam diri seorang anak.

5. Keteladanan dalam mendidik karakter anak adalah sangat penting, apalagi kita sebagai orang tua yang diamanahi Allah berupa anak-anak maka kita harus menjadi teladan yang baik buat mereka. Kita harus bisa menjadi figur yang ideal bagi anak-anak, kita harus menjadi panutan yang bisa mereka andalkan dalam mengarungi kahidupan ini. Jadi, jika kita menginginkan anak-anak kita mencintai Allah dan Rosul-Nya, kita sendiri sebagai orang tua harus mencintai Allah dan Rosul-Nya pula sehingga kecintaan itu akan terlihat oleh anak-anak sebaliknya, jika keteladanan tidak pernah ada, anjuran perkataan orang tuanya mungkin hanya menjadi teori belaka, mereka seperti gudang ilmu yang berjalan namun tidak pernah merealisasikan dalam kehidupan. ${ }^{22}$

Sebagai orangtua, sejatinya selalu ada dalam dirinya melekat semangat transformasi ilmu dan transformasi nilai. Sebab, jika tidak seimbang, orangtua atau suatu institut pendidikan hanya mengisi dimensi intelektualnya semata, namunmengabaikan dimensi emosional dan etika anak-anaknya. Untuk itu, para orangtua ataupun pendidik selain cerdas dan terampil dalam mentransfer ilmu pengetahuan sekaligus menjadi sosok "yang digugu dan ditiru" . sebaliknya, jika tidak demikian, orangtua atau pendidik yang tidak memiliki dimensi keteladanan akan menjadi sosok yang tidak mendapat rasa simpatik dari anak-anaknya. ${ }^{23}$

21 A.H. Maslow, Motivation and Personality ,(New York: Harper and Row, 1984), 24.

22 Amirullah Syarbini, Pendidikan, 122.

${ }^{23}$ Ibid., 123-124. 
Keteladanan adalah cara agar anak meniru karakter seseorang yang menjadi figur untuk di teladani, dalam hal ini khususnya orang tua yang paling penting karena mengingat peran orang tua merupakan pendidik pertama jadi harus memiliki sikap, sifat atau prilaku yang baik demi terciptanya karakter anak yang lebih baik untuk kedepannya.

6. Kebiasaan memainkan peranan yang sangat penting bagi kehidupan seorang anak. Dari kebiasaan-kebiasaan itu kita dapat melihat bagaiman kemungkinan kehidupan seorang anak dimasa depan. Kalau seorang anak memiliki kebiasaan yang baik tentu akan mengantarkan kepada kehidupan yang baik dan bahagia, tetapi ketika seorang anak memilki kebiasaan-kebiasaan yang buruk kemungkinan besar kehidupan yang bersangkutan kedepan tidak anak sesuai dengan yang dia harapkan. Hal ini sejalan dengan bunyi sebuah pepatah, “orangorang tidak bisa menentukan masa depan. Mereka menentukan kebiasaan, dan kebiasaan menentukan masa depan." 24

Kebiasaan adalah pengulangan sesuatu secara terus-menerus atau dalam sebagian besar waktu dengan cara yang sama dan tertanam di dalam jiwa dan diterima atau berubah menjadi tabiat. kebiasaan dalam hal ini mendorongnya untuk melakukan perbuatan-perbuatanya tanpa berpikir menimbang sesuai dengan kebiasaan, baik itu kebiasaan buruk atau baik, semuanya tergantung kebiasaan atau pembiasaan.

7. Peraturan keluarga adalah kebaikan dan kemudaratan. Nilai-nilai kebaikan dari sebuah peraturan harus dapat dicerna oleh anak, demikian juga kemudaratan apabila peraturan itu dilanggar oleh mereka. Dalam konteks ini, orangtua wajib memberikan pemahaman

${ }^{24}$ Ibid., 129. 
kepada anak mengenai pentingnya penegakan disiplin dalam keluarga. ${ }^{25}$

Esensi penegakan aturan adalah meberikan batasan yang tegas dan jelas mana yang harus dan tidak harus dilakukan, serta mana yang boleh dan tidak boleh dikerjakan oleh anak. ${ }^{26}$ Aturan adalah tata tertib yang telah disepakati bersama antar keluarga yang mengajarkan kepada anak apa yang harus dan apa yang boleh dilakukan di rumah atau dalam hubungan dengan anggota keluarga. Dalam hal ini adalah ketaatan dan kepatuhan anak untuk mengerjakan aturan-aturan dalam rumah mereka yang timbul dari proses latihan dan didikan dari kedua orang tuanya agar tercipta hidup yang disiplin.

8. Pendidikan merupakan seperangkat aktivitas atau tahapan kegiatan yang sengaja diciptakan oleh seseorang atau sekelompok orang dalam rangka mencapai tujuan pendidikan yang telah direncanakan. Proses tersebut mengandung arti bahwa aktivitas atau kegiatan yang dilakukan itu setiap saat harus mengaruh pada perubahan yang lebih baik dari sebelumnya. ${ }^{27}$

Dalam proses pendidikan, yang kali pertama harus dilakukan pendidik adalah merumuskan tujuan yang akan dicapai. Tujuan pendidikan yang harus dirumuskan harus mencangkup semua ranah/domain peserta didik, baik kognitif (ingatan, pemahaman, penerapan, analisis, sintesis, evaluasi), efektif (penerimaan, respons, penilaian, pengorganisasian, karakterisasi) maupun psikomotorik (peniruan, manipulasi, ketetapan, artikulasi, pengalamiahan). Setelah merumuskan tujuan, langkah berikutnya ialah menentukan materi

${ }^{25}$ Amirullah Syarbini, Pendidikan, 130.

${ }^{26}$ Aan Hasanah, Pendidikan karakter Berperspektif Islam ,(Bandung: Insan Komunika, 2012), 29.

${ }^{27}$ Amirullah Syarbini, Pendidikan, 132-133. 
pendidikan yang sesuai dengan tujuan tersebut. Selanjutnya menentukan metode pendidikan yang merupakan wahana pengembangan materi pendidikan sehingga dapat diterima dengan baik oleh peserta didik. Kemudian menentukan alat pendidikan yang dapat digunaka untuk memperjelas dan menunjang tercapaianya tujuan tersebut. Langkah yang terakhir adalah menentukan alat evaluasi yang dapat mengukur tercapai tidaknya tujuan yang hasilnya dapat dijadikan feedback bagi pendidik dalam meningkatkan kualitas pendidikan. Instrumen evaluasi yang digunakan untuk mengukur keberhasilan pendidikan tersebut bisa berupa tes atau non tes tergantung sasaran evaluasinya. ${ }^{28}$

Hal yang sama dikatakan Syaiful Sagala bahwa proses pendidikan bermakna upaya pencapaian tujuan pendidikan dengan cara mensinergikan (mengoordinasikan) berbagai komponen pendidikan. ${ }^{29}$ Pendidikan merupakan seperangkat aktifitas terencana yang diaplikasikan melalui proses pembelajaran sebagai upaya untuk meningkatkan pengetahuan, keterampilan, dan pembiasaan baik dalam lingkungan keluarga ataupun pendidikan.

9. Kata pendidik secara fungsional menunjukkan kepada seseorang yang melakukan kegiatan dalam memberikan pengetahuan, keterampilan, pengalaman, dan sebagainya. Orang yang melakukan kegiatan itu bisa siapa saja dan dimana saja. Bisa disekolah, di perguruan tunggi, di tempat kursus, dan bahkan dirumah. ${ }^{30}$

\footnotetext{
28 Ibid., 136-137.

${ }^{29}$ Syaiful Sagala, Manajemen Strategik dalam Peningkatan Mutu Pendidikan ,(Bandung: Alvabeta, 2011), 20.

${ }^{30}$ Amirullah Syarbini, Pendidikan, 144-145.
} 
Dari segi bahasa, pendidik adalahorang yang mendidik. ${ }^{31}$ Pendidik adalah setiap orang yang dengan sengaja mengajar, mempengaruhi membimbing, mengarahkan, dan melatih seseorang agar mencapai kemampuan yang lebih tinggi. Oleh karena itu peran keluarga sangatlah penting sebagai pendidik bagi anak-anaknya agar memiliki karakter yang baik.

10. Peserta didik adalah mereka yang sedang berkembang, baik secar fisik maupun psikis. Peserta didik bukanlah miniatur orang dewasa. Selain itu, mereka juga memiliki berbagai potensi yang harus diarahkan dan dibina agar potensi tersebut bermanfaat. Oleh karenanya, pendidikan karakter adalah sarana tepat untuk itu. ${ }^{32}$

Peserta didik diartikan sebagai anak yang belum dewasa yang tanggung jawabnya diserahkan kepada pendidik. Dala perspertif pendidika secara umum bahwa yang disebut peserta didik adalahsetiapa orang atau sekelompok orang yang harus mendapatkanbimbingan, arahan, dan pengajaran dari proses pendidikan. ${ }^{33}$ Peserta didik merupakan seorang individu yang mengalami fase perkembagan atau pertumbuhan baik dari segi fisik dan mental maupun fikiran. Dalam hal ini sebagai individu yang tengah mengalami fase perkembangan tentu masih banyak memerlukan bimbingan, arahan ataupun bantuan, untuk itu pendidikan karakter sengat diperlukan agar memiliki kepribadian yang baik khususnya pendidikan pertamanya yang dimulai dari dalam keluarga.

\footnotetext{
31Tim Penyusun Kamus Pusat Pembina dan Pengembangan Bahasa, Kamus Besar Bahasa Indonesia ,(Jakarta: Balai Pustaka, 1989), 865.

32 Amirullah Syarbini, Pendidikan, 156.

${ }^{33}$ Muhibbin Syah, Psikologi Pendidikan: Sebuah Pendekatan Baru (Bandung: Remaja Rosdakarya, 1995), 40.
} 
11. Seorang anak akan tumbuh dalam kebaikan dan memiliki karakter yang baik jika ia melihat orangtuanya memberikan teladan yang baik. Sebaliknya, seorang anak akan tumbuh dalam penyelewengan dan memiliki karakter yang buruk. Jika ia melihat orangtuanya memberikan teladan yang buruk. ${ }^{34}$

Metode keteladanan adalah pendidikan meneladankan kepribadian muslim dalam segala aspeknya. Yang, menelaladankan itu tidak hanya orangtua, tetapi seluruh orang kontak dengan anak. ${ }^{35}$ Keteladanan merupakan prilaku seseorang yang patut ditiru atau dicontoh bagi orang yang mengetahuinya atau melihatnya. Dalam hal ini khususnya sebagai orangtua harus membimbing, mengarahkan dan menjadi teladan yang baik bagi sebgai seorang anak agar memiliki karakter yang lebih baik.

12. Metode pembiasaan dalam mebina karakter anak sangatlah penting. Jika metode pembiasaan sudah diterapkan dengan baik dalam keluarga, pasti akan lahir anak-anak yang memiliki karakter yang baik dan tidak mustahil karakter merekapun menjadi teladan bagi orang lain. ${ }^{36}$

Metode pembiasaan menurut Zakiah Daradjat tingkah laku yang baik pada anak sebaiknya dilakukan sejak kecil.37 Pembiasaan merupakan peroses pembentukan sikap dan prilaku yang relatif menetap menjadi kepribadian karena dilakukan secara berulang-ulang. Dalam hal ini orangtua sebagai pendidik, melatih anak membiasakan dalam hal yang baik agar tercipta karakter yang baik dalam diri anak.

\footnotetext{
${ }^{34}$ Amirullah Syarbini, Pendidikan, 169.

${ }^{35}$ Ahmad Tafsir, Filsafat Pendidikan Islami, (Bandung: Remaja Rosda Karya, 2010), 129-130.

36 Amirullah Syarbini, Pendidikan, 171.

37 Zakiah Daradjat, Ilmu Pendidikan Islam, (Jakarta: Raja Wali Press, 1999), 147.
} 
13. Seluruh potensi kecerdasan anak akan berkembang optimal apabila disirami suasana penuh kasih sayang dan jauh dari berbagai tindak kekerasan sehingga anak-anak dapat bermain dengan gembira. Oleh karena itu, kegiatan belajar yan efektif pada anak dilakukan melalui cara-cara bermain aktif yang menyenangkan, dan interaksi pedagogis yang mengutamakan sentuhan emosional, bukan teori akademik. ${ }^{38}$

Seto Mulyadi (psikologi anak), menjelaskan bahwa anak adalah anak, anak bukan manusia dewasa mini, karena itu metode pembelajaran terhadap anak harus disesuaikan dengan perkembangannya. Dunia anak adalah dunia bermain. Pada dasarnya anak senang sekali belajar, asal dilakukan dengan cara-cara bermain yang menyenangkan. ${ }^{39}$ Keluarga sakinah merupakan pondasi utama agar anak mendapatkan siraman kasih sayang dari kedua orangtua diantaranya dengan cara orangtua mengajak bermain seorang anak. Dalam hal ini seorang anak mendapat perhatian dan kesenangan yang dapat membentuk kepribadian dan membantu anak mencapai perkembangan fisik, intelektual, sosial, moral dan emosional.

14. Metode bercerita adalah suatu metode yang mempunyai day tarik yang menyentuh perassaan anak. Islam menyadari sifat alamiah manusia untuk menyenangi cerita yang pengaruhnya besar terhadap perasaan. Oleh karenanya, dijadikan sebagai salah satu teknik dalam mendidik. Adapun tujuan metode bercerita adalah agar pembaca atau pendengar cerita/kisah dapat membedakan perbuatan yang baik dan buruk sehingga dapat diaplikasikan dalam kehidupan sehari-hari. Dengan bercerita, orangtua dapat menanamkan nilai-nilai islam pada anaknya, seperti menunjukkan perbedaan perbuatan baik dan buruk serta ganjaran dari setiap perbuatan. Melalui metode bercerita, diharapkan

\footnotetext{
38 Amirullah Syarbini, Pendidikan, 173.

39 Seto Mulyadi, Memahami Dunia Anak ,( Dalam Kompas, Edisi 13 Juni, 2013), 9.
} 
dapat membedakan perbuatan yang baik dan perbuatan yang buruk sehinngadapat diaplikasikan dalam kehidupan sehari-hari. ${ }^{40}$

Bercerita merupakan suatu kegiatan yang dilakukan seseorang secara lisan kepada orang lain dengan alat atau tanpa alat tentang apa yang harus disampaikan yang berisi pesan, informasi dalam bentuk dongeng untuk diperdengarkan dengan rasa senang oleh karena orang yang menyajikan cerita tersebut menyampaikan dengan menarik.

15. Metode nasehat merupakan metode yang baik untuk membentuk karakter anak. Agar nasehat dapat membekas pada diri anak, sebaiknya nasehat bersifat cerita, kisah, perumpamaan, menggunakn kata-kata yang baik, dan orangtua memberikan contoh terlebih dahulu sebelum memberikan nasehat. ${ }^{41}$

Metode lain yang dinggap representatif dalam membina karakter anak adalah melalui nasehat. Metode nasehat merupakan penyampaian kata-kata yang menyentuh hati dan disertai keteladanan. ${ }^{42}$ metode nasihat merupakan suatu cara untuk membimbing, mengarahkan melalui lisan, tulisan, maupun tindakan. Dalam hal ini sebagai orang tua memberi contoh anak kepada anak dalam hal kebaikan.

16. Metode penghargaan dan hukuman bisa digunakan dalam mendidik karakter anak, tapi penghargaan harus didahulukan daripada hukuman, jika hukuman terpaksa harus diberikan, mak hati-hatilah dalam mempergunakannya, jangan menghukum anak secara berlebihan, jangn menghukum ketika marah, jangan memukul bagian-

40 Amirullah Syarbini, Pendidikan, 178.

41 Ibid., 181.

${ }^{42}$ Amirullah Syarbini, Buku, 85.

Bidayatuna | p-ISSN: 2621-2153, e-ISSN: 0000-0000 | 100 
bagian tertentu fari anggota tubuh anak seperti wajah, dan usahakan hukuman itu bersifat adil (sesuai dengan kesalahan anak). ${ }^{43}$

Metode penghargaan dan hukuman merupakan metode yang digunakan sesuai dengan kondisi anak saat itu. Dalam hal ini metode penghargaan adalah sebuah cara pendidik untuk meningkatkan semangat dalam hal kebaikan yang berbentuk imbalan atas tindakan yang telah di lakukannya. Sedangkan metode hukuman merukan cara untuk mengontrol setiap tindakan buruk yang dilakukan anak dalam hal ini berbentuk sangsi, baik sangsi berupa lisan maupun tindakan semuanya memiliki tujuan mendidik karakter anak agar menjadi lebih baik.

17. Alat pendidikan yang bisa digunakan sesungguhnya sangat banyak, yakni apa saja yang ada di rumah, mulai dari perabotan rumah tangga, permainan anak, sampai alat-alat elektronik seperti televisi, radio, kaset, vcd/dvd, komputer dan lainnya. Tapi penggunaan alat itu bermanfaat atau tidak sangat tergantung pada pengaturan orangtua. Televisi, misalnya, bisa menjadi alat pendidikan karakter anak, tapi bisa juga menjadi penghambat pendidikan anak. Di sini tanggung jawab, peran dan pengaturan dalam menggunakan alat itu ada pada orangtua. 44

Alat pendidikan merupakan sarana-prasarana yang dapat menimbulkan efek negatif dan positif tergantung bagaimana penggunaannya.

18. Evaluasi pendiidkan karakter adalah proses menentukan nilai sesuatu, baik secar kuantitatif maupun kualitatif, berdasarkan pertimbanganpertimbangan tertentu yang berkaitan dengan kegiatan pendidikan karakter dalam keluarga. Tujuan evaluasi pendidikan karakter dalam

${ }^{43}$ Amirullah Syarbini, Pendidikan, 183-184.

${ }^{44}$ Ibid.,185. 
keluarga ini adalah untuk mendapatkan dat objektif yang menunjukkan tingkat kemampuan dan keberhasilan peserta didik dalam mencapai tujuan pendidikan karakter dalam keluarga. ${ }^{45}$

Objek evaluasi pendidikan karakter dalam keluarga lebih ditekankan pada evaluasi perilaku yang menyangkut sikap, minat, perhatian, dan tingkah laku anak sebagai peserta didik. Dapt juga dikatakna bahwa objek evaluasi pendidikan karakter dalam keluarga diarahkan pada evaluasi ranah efektif yang berhubungan dengan penerimaan, tenggapan, penilaian, pengorganisasian, dan karakterisasi anak terhapat suatu nilai atau beberapa nilai yang berlaku dalam keluarga. ${ }^{46}$

Instrumen evaluasi yang digunakan pendidik untuk mengukur keberhasilan kegiatan pendidikan sangat beragam tergantung objek atau sasaran evaluasinya. Karena objek evaluasi pendidikan karakter lebih dominan pada aspek efektif atau perilaku anak, maka alat evaluasi yang digunakan lebih tepat berupa nontes, yaitu dalam bentuk observasi perilaku dan pertanyaan langsung. Observasi dan wawancara dipandang lebih tepat untuk mengukur hasil pendidika yang mengutamakan penampilan anak, karena pada umumnya hasil pendidika yang bersifat penampilan sulit diukur dengan tes. ${ }^{47}$

Menurut Muhibbin Syah, peserta didik merupakan asaran evaluasi yang utama karena letak keberhasilan prose pendidikan biasanya dilihat dari keberhasilan peserta didik. ${ }^{48}$ Evaluasi merupakan suatu bentuk penilaian terhadap setiap tindakan, sikap, maupun tingkat

\footnotetext{
45 Ibid., 190.

46 Ibid., 199-200.

47 Amirullah Syarbini, Pendidikan, 204.

${ }^{48}$ Muhibbin Syah, Psikologi, 211.
} 
kemampuan seseorang. Dalam hal ini diperlukan observasi berupa tes atau nontes.

\section{Kesimpulan}

Berdasarkan analisis data buku Pendidikan Karakter Berbasis Keluarga karya Dr. H. Amirullah Syarbini, M. Ag. Dapat disimpulkan sebagai berikut :

1. pemikiran merupakan sebuah hasil olah pikir yang dapat diterima secara logika dan menjadi sebuah gagasan dari seseorang untuk menguatkan berbagai pendapat/gagasan dari orang lain, dalam hal ini Dr. H. Amirullah Syarbini, M. Ag. dalam bukunya yang berjudul Pendidikan Karakter Berbasis Keluarga memberi penegasan atau hasil olah pikir dari setiap statement para ahli dan Memberikan arahan dari setiap model-model yang ditawarkan sehingga dapat dipahami dan dapat diaplikasikan secara tepat.

2. kekurangan dan kelebihan dalam buku Pendidikan Karakter Berbasis Keluarga karya Dr. H. Amirullah Syarbini, M. Ag. Tidak terlalu mecolok karena setiap model model yang ditawarkan dalam buku ini memiliki sisi negatif dan positif namun tergantung bagaimana pengaplikasiannya. Keluarga merupakan unit atau institusi sosial terkecil yang memiliki peran utama bagi perkembangan karakter anak melalui model-model pengajaran yang diterapkan. Model model yang diterapkan baik berupa pemotivasian, peneladanan, pembiasaan serta penegakan aturan, semuanya menjadi satu tujuan membentuk karakter anak menjadi lebih baik, namun model model yang ditawarkan dalam buku ini memiliki sisi negatif dan positif tergantung bagaimana pengaplikasiannya. Pengaplikasian yang benar akan membentuk pribadi yang baik namun pengaplikasian yang kurang sesuai dengan sikap yang baik, maka akan membentuk pribadi anak kurang baik. 


\section{Daftar Pustaka}

Arikunto Suharsimi, 1998. Menejemen Jurnal. Jakarta: Rineka Cipta.

Arikunto Suharsimi, 1990. Prosedur Jurnal Suatu Pendekatan Praktek. Jakarta : Rineka Cipta.

Darajat Zakiah, 1999. Ilmu Pendidikan Islam. Jakarta: Raja Wali Press.

Hamalik Oemar, 2009. Psikologi Belajar dan Mengajar. Bandung: sinar Baru Algensido.

Hadjar Ibnu, 1996. Dasar-Dasar Metodologi Jurnal Kualitatif Dalam Pendidikan. Jakarta: Raja Grafindo Persada.

Hasanah Aan , 2012. Pendidikan karakter Berperspektif Islam .Bandung: Insan Komunika.

Krippenendorff Klauss, 1993. Analisis isi:pengantar Teori dan Metodologi, terj. Farid Wajidi. Jakarta: Citra Niaga Rajawali Press.

Moeleong Lexy.J, 2006. Metodologi Jurnal Kualitatif. Bandung, Rosdakarya.

Maslow, A. H. 1984. Motivation and Personality. New York: Harper and Row.

Mulyadi Seto. 2013. Memahami Dunia Anak. Dalam Kompas, Edisi 13 Juni 2013.

Muhaimin, Et al. 2008. Paradigma Pendidikan Islam. Bandung: Remaja Rosdakarya.

Nasional Pendidikan Departemen, 2008. Kamus Besar Bahasa indonesia. Jakarta: Pusat Bahasa Depdiknas.

Syarbini Amirullah, 2012. Buku Pintar Pendidikan Karakter. Jakarta : As@Prima Pustaka.

Syarbini Amirullah, 2016.Pendidikan Karakter Berbasis Keluarga. Yogyakarta: Ar-Ruzz Media. 
Muhammad Abdul Halim Sidiq

Rika Fausiyah

Salim, Mohammad Haitami. 2013. Pendidikan Agama dalam Keluarga: Revitalisasi Peran Keluarga dalam Membangun Generasi Bangasa yang Berkarakter. Yogyakarta: Ar-Ruzz Media.

Syah, Muhibbin. 2005. Psikologi Pendidikan. Bandung: Remaja Rosdakarya.

Tim Penyusun Kamus Pusat Pembinaan dan Pengembangan Bahasa. 1989. Kamus Besar Bahasa Indonesia. Jakarta: Balai Pustaka.

Tafsir Ahmad (ed). 2010. Filsafat Pendidikan Islami. Bandung: Remaja Rosdakarya. 